\title{
Exposure of pregnant mice to aluminum and restraint stress: Effects on postnatal development and behavior of the offspring
}

\author{
M. T. COLOMINA, D. J. SANCHEZ, and J. L. DOMINGO \\ Rovira $i$ Virgili University, Reus/Tarragona, Spain \\ and \\ M. SANCHEZ-TURET \\ University of Barcelona, Barcelona, Spain
}

\begin{abstract}
The aim of this study was to assess in mice the potential influence of maternal restraint stress and aluminum $(\mathrm{Al})$ on the postnatal development and behavior of the offspring. On Days 6-15 of gestation, two groups of pregnant mice received intraperitoneal injections of $\mathrm{AlCl}_{3}$ at $75 \mathrm{mg} / \mathrm{kg} / \mathrm{day}$. One of these groups was also subjected to restraint for $2 \mathrm{~h}$ per day during the same days of gestation. Control groups included restrained and unrestrained pregnant mice nonexposed to $\mathrm{Al}$. No significant differences between the groups were noted on maternal food consumption, total body weight change, maternal body weight at termination, or length of gestation. All the animals were allowed to deliver and wean their offspring. The pups were evaluated for physical development and neuromotor maturation. Moreover, open-field activity, motor resistance and coordination, and passive avoidance were also determined on postnatal Days 22,30 , and 60, respectively. The results show that, although an influence of maternal restraint on $\mathrm{Al}$-induced postnatal developmental effects could be observed, the behavior of the offspring was not significantly affected.
\end{abstract}

Until recently, there has been a lack of published observations in relation to the potential developmental toxicity of aluminum (Al) in mammals. However, in recent years, it has been demonstrated that $\mathrm{Al}$ may act as a maternal and developmental toxicant following parenteral exposure. In turn, oral Al can also induce embryo/fetal toxicity, if this element is given in a chemical form that can be absorbed from the gastrointestinal tract (Domingo, 1995, 1997; Golub \& Domingo, 1996).

Dyspepsia is a common complaint in human pregnancy. During gestation, Al-containing antacids are frequently used to reduce the dyspeptic symptoms. Although, in most of these drugs, $\mathrm{Al}$ is present as $\mathrm{Al}$ hydroxide, which has a very low aqueous solubility, the consumption of $\mathrm{Al}$ compounds during pregnancy could mean a potential risk of $\mathrm{Al}$ accumulation, because of the relatively great number of dietary constituents (ascorbate, citrate, lactate, succinate, etc.) that can enhance the gastrointestinal Al absorption (Domingo, Gomez, Llobet, \& Corbella, 1991).

In experimental animals, it has been shown that parenteral and oral $\mathrm{Al}$ administration during gestation can cause a developmental syndrome that includes in utero death, malformations, growth restriction, and neurodevelopmental delay (Domingo, 1995; Golub \& Domingo, 1996).

This work was supported by the DGICYT, Ministry of Education, Spain, through Grant PM96-0030. Correspondence concerning this article should be addressed to J. L. Domingo, School of Medicine, URV, San Lorenzo 21, Reus 43201, Spain (e-mail: jlldr@fmcs.urv.es).
Moreover, it has also been demonstrated that, during gestation and lactation, an excess of $\mathrm{Al}$ at levels that do not produce maternal toxicity can result in persistent neurobehavioral deficits in the offspring (Bernuzzi, Desor, \& Lehr, 1989a, 1989b; Donald, Golub, Gershwin, \& Keen, 1989; Golub, Donald, Gershwin, \& Keen, 1989; Golub, Keen, \& Gershwin, 1992; Muller, Hutin, Burnel, \& Lehr, 1992; Yokel, 1989).

On the other hand, it is now well established that maternal stress during gestation can also produce significant embryo/fetal toxicity and/or postnatal effects (Beyer \& Chernoff, 1986; Chernoff, Miller, Rosen, \& Mattscheck, 1988; Chernoff, Rogers, \& Kavlock, 1989; Scialli, 1988). Maternal stress, which can range from physical to psychological, from mild to severe, and from obvious to unrecognized (Vogel, 1993), can be induced by a number of diverse causes. Maternal stress in combination with known developmental toxicants has been shown to enhance the developmental toxicity of these agents. Among the animal models that have been used to evaluate the effects of maternal stress on the developmental toxicity of a chemical, restraint has been widely used, with positive and negative results. Although some studies have shown that maternal restraint could significantly exacerbate the maternal and embryo/fetal toxicity of toxicants such as methylmercury (Colomina, Albina, Domingo, \& Corbella, 1995) and arsenate (Rasco \& Hood, 1994), other investigations have failed to find any modification in the developmental or neurobehavioral toxicity of arsenite (Colomina, Albina, Domingo, \& Corbella, 
1996) or of concurrent exposure to ethanol and methylmercury (Colomina, Sanchez, Albina, Domingo, \& Corbella, 1997).

Inasmuch as both $\mathrm{Al}$ and maternal stress during pregnancy have been shown to produce developmental effects in mammals and since, potentially, pregnant women may be exposed to $\mathrm{Al}$ (through food, drinking water, or medications) and to various types of stress, either at home or in the workplace, we assessed the developmental toxicity in mice of a combined exposure to Al and maternal restraint stress in a recent study (Colomina, Esparza, Corbella, \& Domingo, 1998). The results showed that maternal restraint could enhance Al-induced developmental toxicity only at doses of the metal that were also toxic to the dam (Colomina et al., 1998). Because maternal restraint stress and $\mathrm{Al}$ can also induce behavioral changes in mammals, the purpose of the present study is to evaluate in mice whether maternal restraint stress can alter the effects of parenteral Al exposure on the postnatal development and behavior of offspring.

\section{METHOD}

\begin{abstract}
Animals and Housing
Sexually mature male and female Swiss mice (28-32 g) were obtained from Interfauna Iberica (Barcelona, Spain). The animals were housed in plastic cages in a fully air-conditioned facility with a constant day-night cycle (light: $0800-2000 \mathrm{~h}$ ) at a temperature of $22^{\circ} \pm 2^{\circ} \mathrm{C}$, and a relative humidity of $50 \% \pm 10 \%$. After a quarantine period of 7 days, the female mice were mated with males $(2: 1)$ overnight and were examined the following morning for copulatory plugs. The day on which a vaginal plug was found was designated as Day 0 of gestation. All the mice were allowed free access to food (Panlab rodent chow, Barcelona) and tap water. Aluminum concentration in the diet and water were $0.257 \mathrm{~g} / \mathrm{kg}$ and $0.052 \mu \mathrm{g} / \mathrm{ml}$, respectively.
\end{abstract}

\section{Chemical}

Aluminum chloride anhydrous $\left(\mathrm{AlCl}_{3}\right)$ was obtained from Sigma (Alcobendas, Spain). It was administered in aqueous solutions at $75 \mathrm{mg} / \mathrm{kg}$. The choice of this dose was based on the results of a recent study on developmental toxicity of $\mathrm{Al}$ in mice (Colomina et al., 1998). Solutions were injected intraperitoneally (i.p.) at $\mathrm{pH} 4.0$ and adjusted so that a $30-\mathrm{g}$ mouse would receive a volume of $0.20 \mathrm{ml}$.

\section{Treatment}

Plug-positive female mice were randomly divided into four groups and received the following treatments on Days 6-15 of gestation. The first group of animals (control group) was unrestrained and was injected with $0.9 \%$ saline acidified with $\mathrm{HCl}$ to a pH of 4.0 . The second group of mice (restrained control group) was injected with $0.9 \%$ saline acidified with $\mathrm{HCl}$ to a $\mathrm{pH}$ of 0.4 and was restrained daily for $2 \mathrm{~h}(1000-1200 \mathrm{~h})$ by placing the animals in plastic cylindrical holders that were lined with foam padding. The restrained mice were held in a prone position and were monitored periodically. The animals in the third group were given an i.p. injection of $75 \mathrm{mg} / \mathrm{kg} /$ day of aqueous $\mathrm{AlCl}_{3}$ solutions $(\mathrm{pH}=4.0)$. These mice were unrestrained. Finally, plug-positive female mice in the fourth group (combined $\mathrm{AlCl}_{3}$ and restraint group) received i.p. injections of $75 \mathrm{mg} / \mathrm{kg} /$ day of $\mathrm{AlCl}_{3}$ at $\mathrm{pH}=4.0$, followed by restraint stress for $2 \mathrm{~h} /$ day on Days 6-15 of pregnancy. Body weight and food consumption were monitored daily.

\section{Data Collection}

Physical and functional assessment. Pregnant mice were allowed to deliver and wean their offspring. At birth, the following data were recorded: length of gestation, number of live and dead pups, sex, and individual pup weights. Litter sizes were then reduced to 8 pups. A sex ratio of 4:4 was aimed at; otherwise, the selection of pups was random. Pup weights were again measured on postnatal Days 4, 8, and 21. The developmental landmarks of pinna detachment, incisor eruption, eye opening, vaginal opening, and testes descent were also monitored.

Neuromotor maturation. In order to assess general neurotoxic effects, 1 pup of each sex in each litter was subjected to a routine testing battery (Colomina et al., 1996; Colomina, Sanchez, et al., 1997; Suter \& Schön, 1986).

A surface righting reflex test was conducted on postnatal Days 3-9. The pups were directly placed on their back on a horizontal board and were released. Time spent to return to the normal dorsoventral position was measured.

A negative geotaxis test was conducted on postnatal Days 9-15. The animals were placed in a $30^{\circ}$ inclined screen, and the time spent in turning up was recorded.

A forelimb grip strength test was conducted on postnatal Days 9-15. The pup's forelimbs were placed on a thin wire attached to the pull gauage until the animal grasped the wire. Subsequently, the pup was pulled, and the maximum strength on three consecutive trials was recorded.

Postweaning tests. An open-field activity test was conducted on postnatal Day 22. General motor activity was measured in an openfield apparatus, consisting of a wood $38 \times 38 \mathrm{~cm}$ square surrounded by a $47-\mathrm{cm}$-high dark wall. During the test, the mice were allowed to move freely around the open field and to explore the environment for $10 \mathrm{~min}$. The path of the animals was recorded by a video camera (Sony CCD-IRIS model) that was placed above the square and was connected to a VHS videocassette recorder (Panasonic AG-5700 model). The video tracking program Etho-Vision from Noldus Information Technologies (Wageningen, The Netherlands) was used to measure the total distance traveled and the number of rearings as a measure of vertical activity (Sanchez, Colomina, \& Domingo, 1998).

A rotarod test was conducted on postnatal Day 30 . Motor resistance and coordination were evaluated in a rotarod apparatus (Letica, Barcelona, Spain), which consisted of a rotating rod running from 0 to $40 \mathrm{rpm}$. The animals were trained for three trials of $60 \mathrm{sec}$ (maximum) at $10 \mathrm{rpm}$. Immediately after training, the animals were placed in the rod at an initial speed of $10 \mathrm{rpm}$, increasing $7 \mathrm{rpm}$ every minute. The time spent on the rod, up to $5 \mathrm{~min}$, in three consecutive trials was recorded, and the best score was used for statistical analyses.

A passive avoidance test was conducted on postnatal Day 60 . Earning ability was evaluated in 1 male of each litter. The apparatus consisted of a shuttle box separated into two compartments by a wall and a sash door (Ugo Basile, Comerio, Italy). One compartment $(10 \times 18 \mathrm{~cm})$ was illuminated, and the other $(10 \times 18 \mathrm{~cm})$ was dark. The animals were placed in the illuminated compartment, and after a period of $30 \mathrm{sec}$, the door was pulled up. After some seconds, the mice spontaneously entered the dark compartment (T1). The door was shut $1 \mathrm{sec}$ after the crossing, and the animals received an electric shock of $0.3 \mathrm{~mA}$ for $3 \mathrm{sec}$. Twenty-four $\mathrm{h}$ later the same procedure was repeated without a delay period before opening the door and without an electric shock. The time elapsed before entering the dark compartment was recorded as $\mathrm{T} 2$.

\section{Statistical Analysis}

The litter was the unit of statistical analysis. For the analysis of body weight and developmental landmark data, the mean value of each sex in each litter was used. Developmental landmarks were 
evaluated with a three-way analysis of variance (ANOVA). Body weight, neuromotor development, and open-field activity data were analyzed with a three-way ANOVA for repeated measures, using age as the repeated measure and $\mathrm{Al}$ treatment, restraint, and sex as factors. Significant treatment-related interactions were further analyzed, using the simple effect at each level of interaction, with Bonferroni corrections for multiple comparisons. To evaluate the effects of $\mathrm{Al}$, restraint, and day of testing on passive avoidance conditioning, a two-way ANOVA for repeated measures, with day of testing as the repeated measure, was used. A probability value of $p<.05$ was considered to be significant.

\section{RESULTS}

\section{Maternal Effects}

One dam in the Al-treated group and 1 dam in the group exposed to Al plus restraint died during the treatment period, and some abortions were also observed in all the groups (control group, one; restraint only, two; $\mathrm{Al}$ only, one; Al plus restraint, two). However, the differences among groups were not statistically significant and were not attributed to treatment. No significant effects of $\mathrm{Al}$ or restraint could be observed on maternal food consumption, total body weight change (Days $0-18$ ), body weight change during the treatment period, or body weight at termination (Table 1). However, a two-way (Al $\times$ restraint) ANOVA showed an overall effect of restraint and an interaction of $\mathrm{Al}$ and restraint on maternal body weight change on gestation Days $15-18[F(1,37)=$ $14.086, p=.001 ; F(1,37)=4.980, p=.032]$.

\section{Physical and Functional Assessments}

There were no differences among the four groups with respect to the length of gestation (Table 2). In relation to pup body weight, an ANOVA for repeated measures, taking age as the repeated measure and Al treatment, sex, and restraint stress as factors, showed an interaction of restraint and age $[F(3,54)=38.13, p<.001]$ and of $\mathrm{Al}$ and age $[F(3,54)=63.36, p<.001]$, as well as an inter-

Table 1

Effects of $\mathrm{AlCl}_{3}$, Restraint, and Combined $\mathrm{AlCl}_{3}$ and Restraint on Maternal Toxicity in Pregnant Mice

\begin{tabular}{|c|c|c|c|c|c|c|c|c|}
\hline \multirow[b]{2}{*}{ Effect } & \multicolumn{2}{|c|}{$\begin{array}{l}\text { Control Group } \\
\quad(n=10)\end{array}$} & \multicolumn{2}{|c|}{$\begin{array}{l}\text { Restraint Only } \\
\quad(n=11)\end{array}$} & \multicolumn{2}{|c|}{$\begin{array}{l}\text { Aluminum Chloride } \\
\qquad(n=9)\end{array}$} & \multicolumn{2}{|c|}{$\begin{array}{l}\text { Aluminum Chloride } \\
\text { Plus Restraint } \\
(n=10)\end{array}$} \\
\hline & $M$ & $S D$ & $M$ & $S D$ & $M$ & $S D$ & $M$ & $S D$ \\
\hline $\begin{array}{l}\text { Food consumption }(\mathrm{g} / \mathrm{dam}) \\
\text { on gestation days } 0-18\end{array}$ & 120.67 & 28.64 & 112.85 & 12.29 & 107.40 & 2.17 & 97.10 & 13.10 \\
\hline $\begin{array}{l}\text { Total body weight change (g) } \\
\text { on gestation days } 0-18\end{array}$ & 22.75 & 5.75 & 25.42 & 2.94 & 22.93 & 3.25 & 23.03 & 3.94 \\
\hline $\begin{array}{l}\text { Body weight change (g) during } \\
\text { the treatment period (Days 6-15) }\end{array}$ & 10.63 & 3.42 & 8.93 & 2.12 & 9.58 & 1.84 & 8.78 & 2.33 \\
\hline $\begin{array}{l}\text { Body weight change (g) after } \\
\text { the treatment period (Days 15-18) } \\
\text { Body weight at termination (g) }\end{array}$ & $\begin{array}{l}9.13^{*} \\
51.00\end{array}$ & $\begin{array}{l}2.36 \\
6.39\end{array}$ & $\begin{array}{l}13.05 \dagger \\
53.40\end{array}$ & $\begin{array}{l}2.00 \\
3.58\end{array}$ & $\begin{array}{l}10.13^{*} \ddagger \\
51.93\end{array}$ & $\begin{array}{l}0.85 \\
3.26\end{array}$ & $\begin{array}{l}11.13 \ddagger \\
49.38\end{array}$ & $\begin{array}{l}2.41 \\
4.47\end{array}$ \\
\hline
\end{tabular}

Table 2

Physical and Functional Assessment in the Offspring of Mice Exposed to $\mathrm{AlCl}_{3}$, Restraint, and Combined $\mathrm{AlCl}_{3}$ and Restraint on Gestation Days 6-15

\begin{tabular}{|c|c|c|c|c|c|c|c|c|}
\hline \multirow[b]{2}{*}{ Assessment } & \multicolumn{2}{|c|}{$\begin{array}{l}\text { Control Group } \\
(n=10)\end{array}$} & \multicolumn{2}{|c|}{$\begin{array}{l}\text { Restraint Only } \\
\quad(n=11)\end{array}$} & \multicolumn{2}{|c|}{$\begin{array}{l}\text { Aluminum Chloride } \\
\qquad(n=9)\end{array}$} & \multicolumn{2}{|c|}{$\begin{array}{l}\text { Aluminum Chloride } \\
\text { Plus Restraint } \\
(n=10)\end{array}$} \\
\hline & $M$ & $S D$ & $M$ & $S D$ & $M$ & $S D$ & $M$ & $S D$ \\
\hline Length of gestation & 19 & & 19 & & 19 & & 19 & \\
\hline No. of fetuses/litter & 9 & 2.90 & 10.1 & 1.39 & 10.7 & 1.91 & 8.5 & 2.61 \\
\hline Viability index $(\%)$ & 100 & & 100 & & 100 & & 94.11 & \\
\hline Lactation index $(\%)$ & 100 & & 100 & & 100 & & 88.75 & \\
\hline \multicolumn{9}{|l|}{ No. of days at pinna detachment } \\
\hline Males & $3.60^{*}$ & 0.68 & $4.23^{*}$ & 0.33 & $4.61 \dagger$ & 0.45 & $4.86 \dagger^{\dagger}$ & 0.55 \\
\hline Females & $3.64^{*}$ & 0.65 & $4.30^{*}$ & 0.38 & $4.64 \dagger$ & 0.45 & $4.84 \dagger$ & 0.52 \\
\hline \multicolumn{9}{|l|}{ No. of days at incisor erupt } \\
\hline Males & $5.50^{*}$ & 0.55 & $6.16^{*}$ & 0.59 & $6.25^{*}$ & 0.66 & $7.70 \dagger$ & 0.54 \\
\hline Females & $5.51^{*}$ & 0.50 & $6.20^{*}$ & 0.59 & $6.29 *$ & 0.65 & $7.90 \dagger$ & 0.49 \\
\hline \multicolumn{9}{|l|}{ No. of days at eye opening } \\
\hline Males & $13.55^{*}$ & 0.52 & $14.18 * \dagger$ & 0.54 & $14.86+t$ & 0.63 & $15.22 \ddagger$ & 0.49 \\
\hline Females & $13.67^{*}$ & 0.59 & $14.14^{*}$ & 0.54 & $15.00 \dagger$ & 0.76 & $14.96 \dagger$ & 0.56 \\
\hline No. of days at testes descent & $25.33^{*}$ & 0.82 & $25.83 \dagger$ & 0.44 & $25.88 * \dagger$ & 0.80 & $26.81 \dagger$ & 1.19 \\
\hline No. of days at vagina opening & $25.54^{*}$ & 0.60 & $26.21^{*}$ & 0.98 & $26.59^{*}$ & 1.46 & $28.45 \dagger$ & 0.94 \\
\hline
\end{tabular}


action between age, restraint stress, and $\mathrm{Al}[F(3,54)=$ $28.87, p<.001]$, and an overall effect of sex $[F(1,56)=$ $3.25, p=.032]$, restraint $[F(1,56)=56.82, p<.001]$, and $\mathrm{Al}[F(1,56)=117.66, p<.001]$. On postnatal Days 4,8 , and 21 , male pups in the group exposed to Al plus restraint showed a reduction in body weight in relation to those in the unrestrained control group, whereas in females, decreases in body weight were noted only on postnatal Days 8 and 21 (Figure 1).

\section{Developmental Landmarks}

Although, in the group exposed to Al plus restraint, the viability index (live pups on Day 4:live pups at birth) and the lactation index (live pups on Day 21 :live pups on Day 4) were slightly lower than those noted in the remaining three groups, the differences did not reach the level of statistical significance (Table 2). A three-way
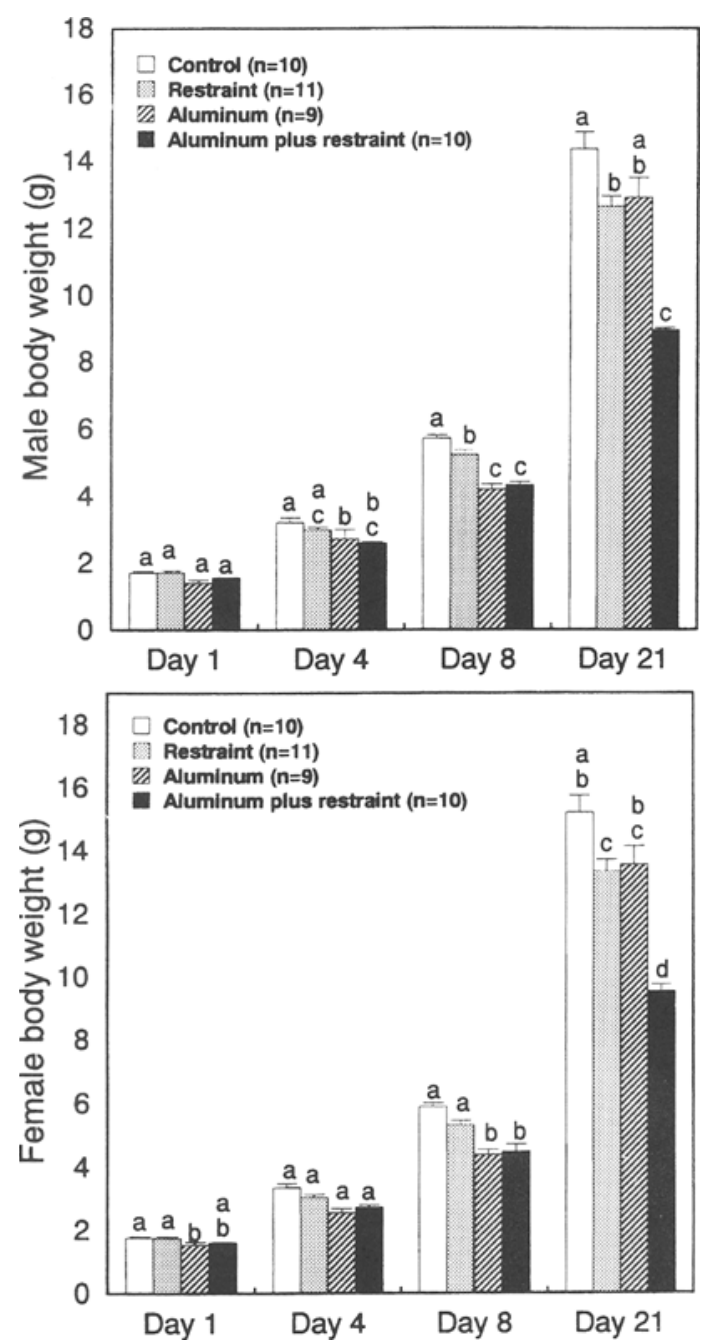

Figure 1. Body weight of male and female pups during the lactation period. For each day, values not showing a common letter $(a, b, c, d)$ are significantly different at $p<.05$.
ANOVA ( $\operatorname{sex} \times \mathrm{Al} \times$ restraint) showed an overall effect of $\mathrm{Al}$ and an overall effect of restraint on pinna detachment $[F(1,65)=41.37, p<.001 ; F(1,65)=12.28, p=$ $.001]$, incisor eruption $[F(1,65)=56.90, p<.001$; $F(1,65)=66.62, p<.001]$, and eye opening $[F(1,65)=$ $57.93, p<.001 ; F(1,65)=5.81, p<.019]$, as well as an interaction between $\mathrm{Al}$ and restraint on incisor eruption $[F(1,65)=8.52, p=.005]$. In turn, a two-way ANOVA (Al $\times$ restraint) showed an overall effect of $\mathrm{Al}$ and restraint $[F(1,29)=5.99, p=.021 ; F(1,29)=5.24, p=$ $.030]$ on female vagina opening and an overall effect of $\mathrm{Al}$ and restraint on male testes descent $[F(1,28)=17.74$, $p<.001 ; F(1,28)=10.54, p=.003]$.

\section{Neuromotor Development}

An ANOVA for repeated measures, using Al exposure, restraint stress, and sex as factors and age as the repeated measure, revealed neither different effects of sex interacting with age nor an overall effect of sex. According to this, the effects of $\mathrm{Al}$ treatment or restraint stress on surface righting reflex, negative geotaxis, and forelimb grip strength were jointly evaluated for both sexes.

Surface righting. An ANOVA for repeated measures revealed an interaction between age and $\mathrm{Al}$ exposure, as well as an interaction between age, $\mathrm{Al}$ treatment, and restraint $[F(6,36)=6.10, p<.001 ; F(6,36)=4.27, p=$ $.002]$. It indicated different sensitivity periods for this test. Post hoc analysis between groups for each day of testing revealed that only the pups in the group given $\mathrm{Al}$ alone showed an increased latency period to return to the normal dorsoventral position on Days 5, 6, and 7, in comparison with the other three groups. No other differences could be observed (Figure 2).

Forelimb grip strength. An ANOVA for repeated measures revealed interactions between the postnatal day of testing and $\mathrm{Al}$ treatment and between age, restraint stress, and $\mathrm{Al}[F(6,25)=4.45, p=.003 ; F(6,25)=3.39$, $p=.014]$. The pups in the group exposed to $\mathrm{Al}$ and restraint showed significant differences in all the days tested when compared with the remaining groups. These differences increased with the age of the animals (Figure 3).

Negative geotaxis. No significant differences among groups were observed on this test.

\section{Postweaning Tests}

Open-field activity. An ANOVA for repeated measures, using Al treatment, restraint stress, and sex as factors and day of testing as the repeated measure, showed an effect of day of testing, which is an indicator of habituation, an interaction between day of testing and sex, as well as an interaction between sex, restraint stress, and day of testing $[F(2,32)=12.47, p<.001 ; F(2,32)=4.49$, $p=.019 ; F(2,32)=4.43, p=.020]$ on total distance traveled (Figure 4). Moreover, an effect of day of testing, an interaction between sex and day of testing, and an interaction between sex, restraint stress, and day of testing $[F(2,32)=5.26, p=.011 ; F(2,32)=4.57, p=.018$; 


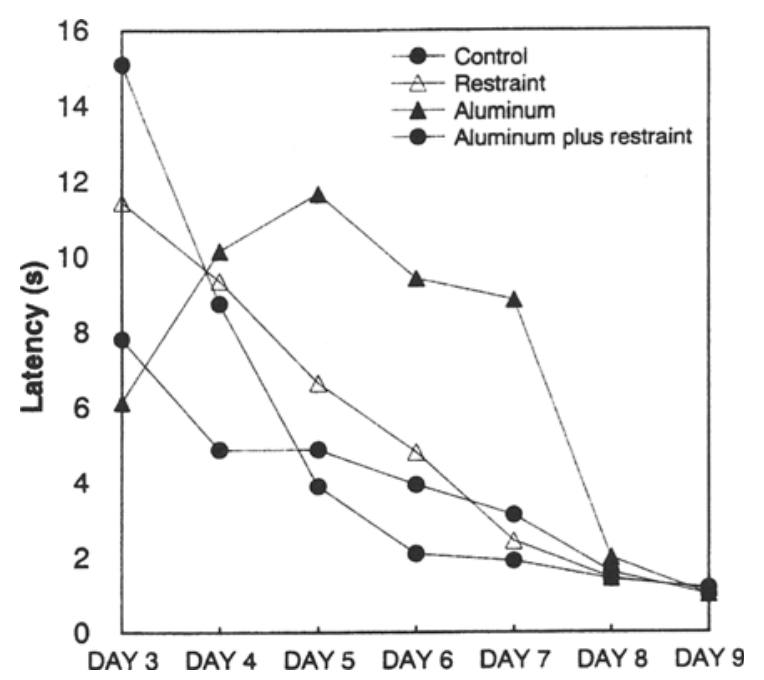

Figure 2. Evolution of surface righting reflex on mice exposed prenatally to saline $(n=8)$, restraint $(n=8)$, aluminum $(n=8)$, or aluminum plus restraint $(n=10)$.

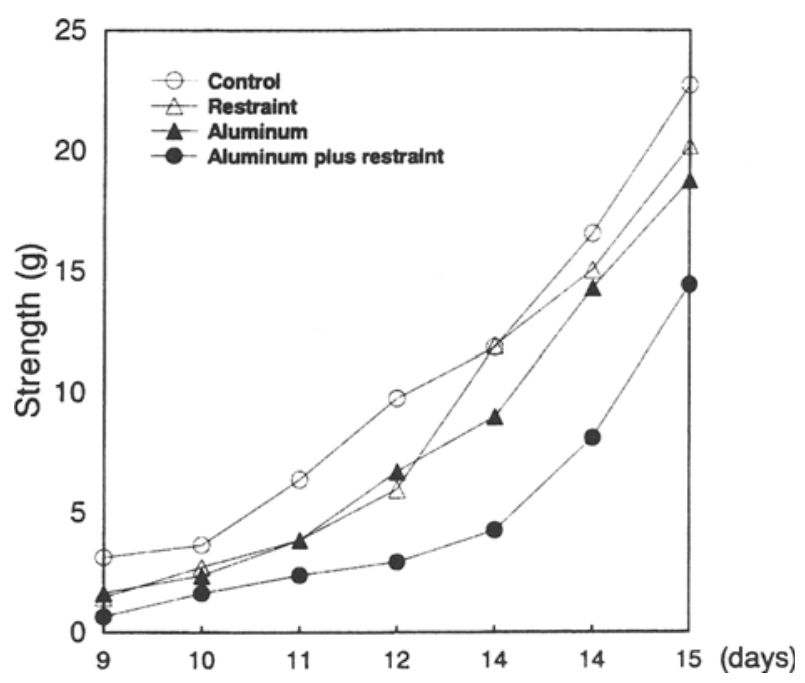

Figure 3. Evolution of forelimb grip strength on mice exposed prenatally to saline $(n=8)$, restraint $(n=8)$, aluminum $(n=8)$, or aluminum plus restraint $(n=10)$.

$F(2,32)=4.33, p=.022$ ] on the number of rearings was also found (Figure 5). However, no significant effects of $\mathrm{Al}$ or of $\mathrm{Al}$ plus restraint were seen. Consequently, post hoc comparisons between groups were not conducted.

Rotarod. A two-way ANOVA (AI $\times$ restraint) showed an interaction between restraint and $\mathrm{Al}$ treatment $[F(1,39)=$ $4.32, p=.045]$ on total time spent on a rotarod. Although no significant differences among groups were found, the animals in the group given $\mathrm{Al}$ only spent less time in the rotarod than did those in the control group $(p=.059)$. The interaction between $\mathrm{Al}$ and restraint reduced the effects of $\mathrm{Al}$ on the rotarod (Figure 6).
Passive avoidance. A two-way ANOVA $(\mathrm{Al} \times$ restraint) for repeated measures, using day of the test as the repeated measure, showed an overall effect of day of testing $[F(1,25)=12.68, p=.002]$, which indicates retention of the initial conditioning. No significant effects of $\mathrm{Al}$, restraint, or Al plus restraint were noted. However, according to the data shown in Figure 7, an apparent impaired performance can be observed in this test.

\section{DISCUSSION}

Despite the potential interest in the influence of maternal stress on the developmental and neurobehavioral toxicity of metals, studies about it are rather scarce. Although Ferm and Kilham (1977) reported that treatment

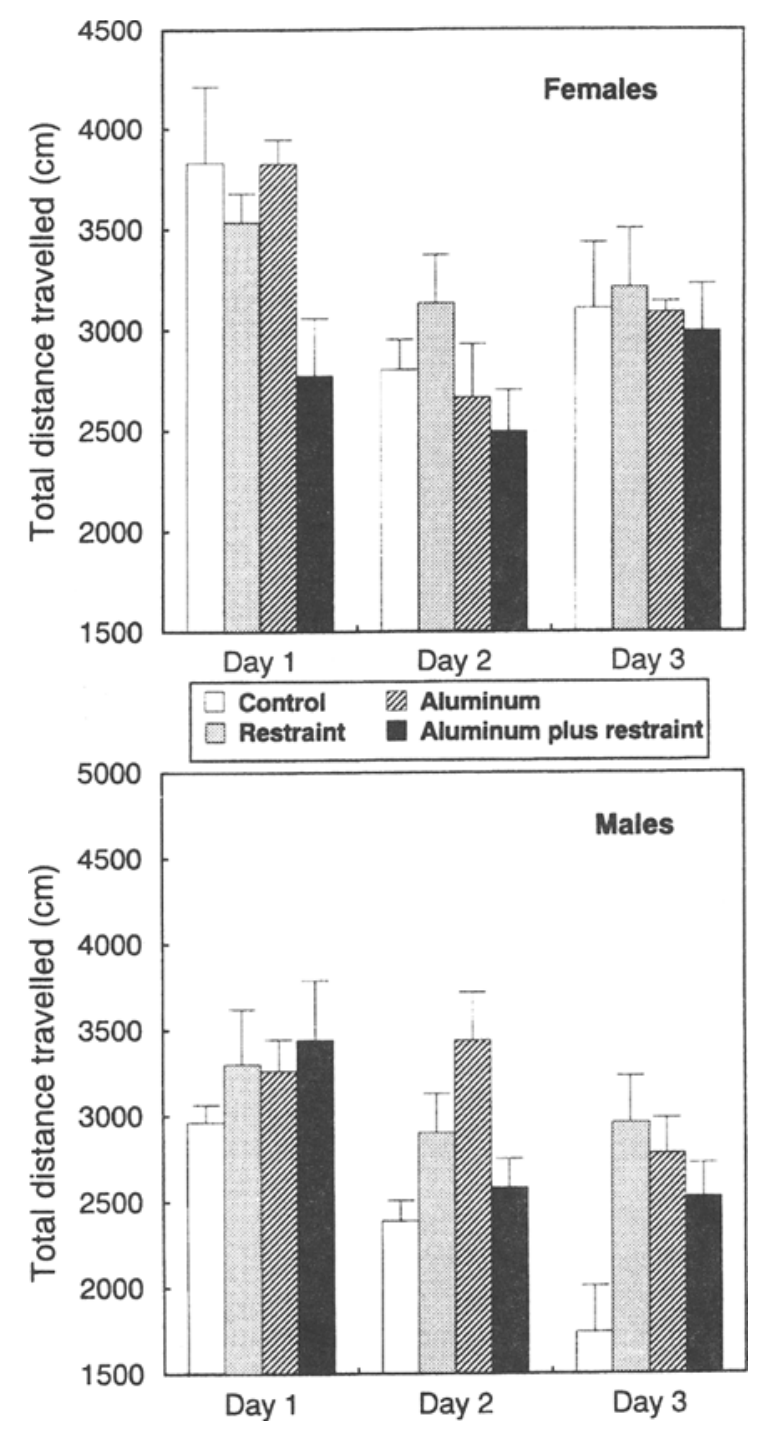

Figure 4. Horizontal activity in an open field (mean $\pm S E$ ) of mice exposed prenatally to saline $(n=8)$, restraint $(n=8)$, aluminum $(n=8)$, or aluminum plus restraint $(n=10)$. 

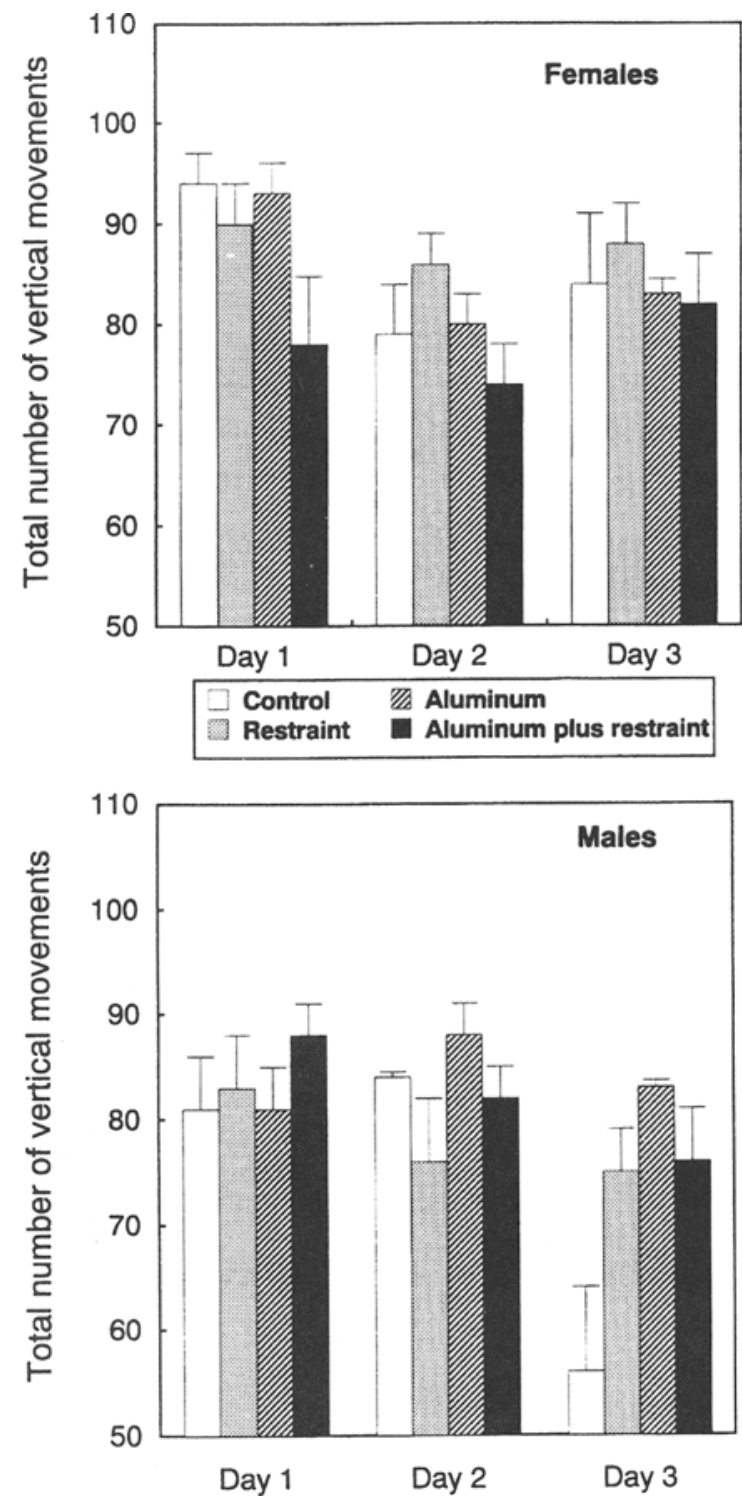

Figure 5. Vertical activity in an open field (mean $\pm S E$ ) of mice exposed prenatally to saline $(n=8)$, restraint $(n=8)$, aluminum $(n=8)$, or aluminum plus restraint $(n=10)$.

of pregnant hamsters with sodium arsenate and hyperthermia on Day 8 of gestation caused synergistic teratogenic effects at minimal levels of each, maternal restraint did not enhance the arsenite-induced embryo/fetal and neurobehavioral toxicity in mice at doses that are not teratogenic by themselves (Colomina et al., 1996). On the other hand, maternal restraint stress was found to potentiate the embryo/fetal toxicity of arsenate (Rasco \& Hood, 1994) and methylmercury (Colomina et al., 1995), but not the neurobehavioral toxicity of arsenate or methylmercury in mice (Colomina, Albina, Domingo, \& Corbella, 1997). In turn, Murata and co-workers (Murata, Takigawa, \& Sakamoto, 1993) did not find any modifi- cation of the cadmium-induced teratogenicity following concurrent exposure of pregnant mice to noise and cadmium. In this study, the effects on the postnatal development and behavior of the offspring of maternal restraint and $\mathrm{Al}$ were evaluated in pregnant mice. Aluminum was given at a dose $(75 \mathrm{mg} / \mathrm{kg} /$ day $)$ that did not produce any notable signs of maternal toxicity.

The developmental effects observed in the present study occurred with an $\mathrm{Al}$ dose $(75 \mathrm{mg} / \mathrm{kg} /$ day $)$ that did not produce any notable signs of maternal toxicity. No significant differences between groups were observed on maternal food consumption, total body weight change, body weight at termination, or length of gestation. The effects of parenteral $\mathrm{Al}$ on development are in agreement with the results of previous studies showing a dosedependent delay in the growth of pups of Al-treated rats, which received Al nitrate orally for 14 days prior to mating, with the treatment being continued throughout gestation, parturition, and lactation (Domingo, Paternain, Llobet, \& Corbella, 1987a). The growth of the offspring was also significantly delayed when Al nitrate was given orally to pregnant rats from birth throughout lactation (Domingo, Paternain, Llobet, \& Corbella, 1987b).

Yokel $(1984,1985,1987)$ reported few effects in the suckling offspring of rabbits whose does received subcutaneous (s.c.) injections of Al lactate at doses of between 0.68 and $21.6 \mathrm{mg} \mathrm{Al} / \mathrm{kg} /$ injection, which was attributed to a probable limited distribution of $\mathrm{Al}$ into milk, together with a poor gastrointestinal Al absorption (Yokel, 1984; Yokel \& McNamara, 1985). These studies, as well as other investigations conducted on rats and mice, indicated that $\mathrm{Al}$ is present in the milk of $\mathrm{Al}$-exposed dams but that it would not readily accumulate in pups during lactation (Golub \& Domingo, 1996). By contrast, although Al concentrations in the placenta that were four- to fivefold higher than those in most fetal or maternal soft tissues of

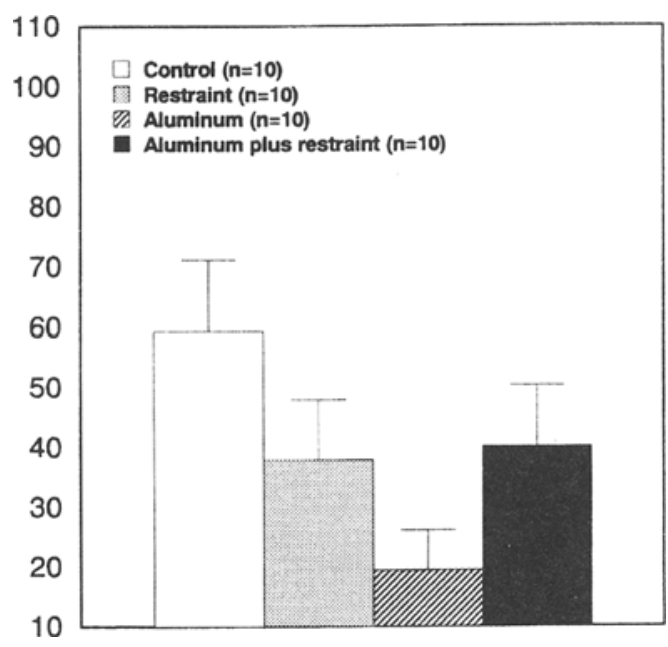

Figure 6. Time spent (in seconds) on a rotarod (mean values \pm $S E$ ). 


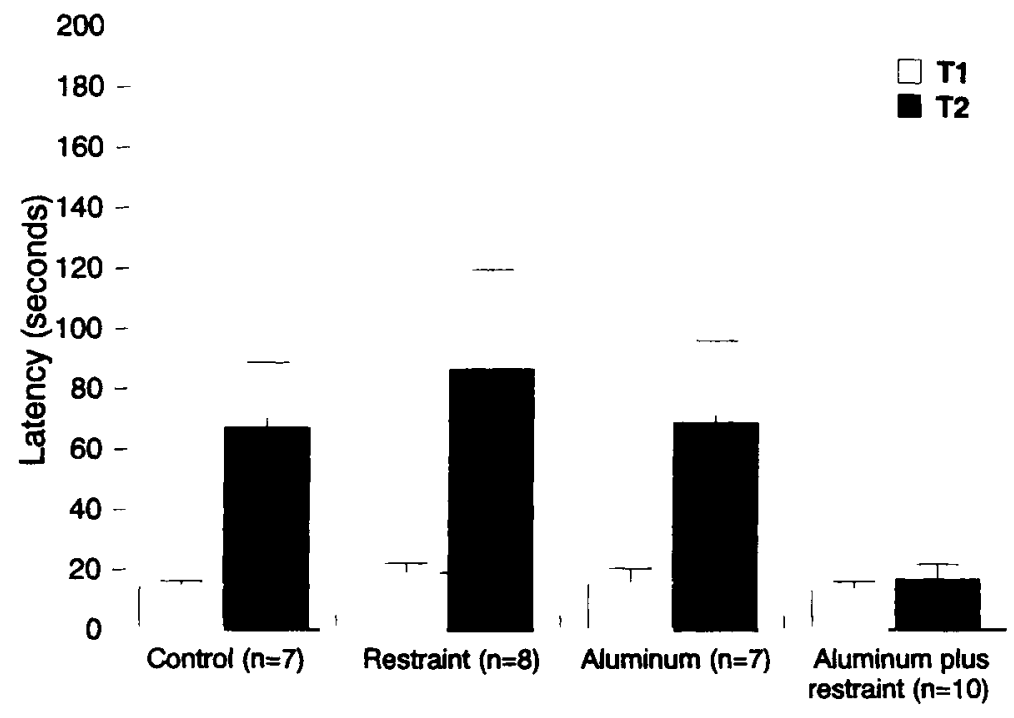

Figure 7. Passive avoidance conditioning (mean values $\pm S E$ ) of $\mathrm{T} 1$ and $\mathrm{T} 2$.

rabbits and mice were found, accumulation in the placenta did not apparently lessen or prevent $\mathrm{Al}$ accumulation in the fetus (Golub \& Domingo, 1996). Therefore, the delay on postnatal development of the pups found in the present study was probably due to an $\mathrm{Al}$ accumulation in the fetuses, rather than to $\mathrm{Al}$ absorption from the milk of the dam. However, a lack of remarkable Al transfer with lactation does not necessarily indicate that elevated $\mathrm{Al}$ in milk does not cause adverse effects on the offspring. In relation to it, Golub and co-workers (Golub, Han, \& Keen, 1996) showed that nursing pups of mouse dams fed excess $\mathrm{Al}$ in their diet had a poor retention of iron and manganese from a milk meal. On the other hand, s.c. administration of Al lactate $(2.5-10 \mathrm{mg} / \mathrm{kg} /$ day) to rats on gestational Days 7-15 had no effect on birthweight, mean litter size, and the day of eye and ear opening (Gonda, Lehotzky, \& Miklosi, 1996). Similar findings were also reported by Muller et al. (1990) and Yokel (1985). As in the present study, Muller et al. showed that gestational $\mathrm{Al}$ treatment had no effects on pup mortality rates.

In recent years, a number of studies conducted in rats and mice showed that maternal oral Al exposure altered performance on a neurobehavioral test battery, specifically impaired negative geotaxis, and reduced forelimb and hindlimb grip strength (Bernuzzi et al., 1989a, 1989b; Golub, Gershwin, Donald, Negri, \& Keen, 1987; Golub et al., 1992). In the present study, the surface righting reflex was affected mainly in the group exposed to Al only. However, similar values were seen on postnatal Day 8 for all the groups, which indicates only a delay in this reflex. By contrast, differences in forelimb grip strength between groups remained on postnatal Day 15, which could indicate long-lasting effects of $\mathrm{Al}$ or restraint. Similar results were also reported in mice exposed to dietary alumi- num during development (Golub, Han, Keen, Gershwin, \& Tarara, 1995).

Prenatal Al exposure, alone or plus restraint, did not cause significant changes in the activity of the offspring measured in an open field. A diminished horizontal activity was reported in rats prenatally exposed to Al lactate (Gonda et al., 1996). A markedly reduced activity level during behavioral testing was reported in adult rats after developmental Al exposure (Cherroret et al., 1992; Muller et al., 1990). However, no deficits in the test of delayed alterations (Golub et al., 1996), in the radial maze (Cherroret et al., 1992), or in the operant light avoidance task (Muller et al., 1990) were found in adult mice and rats exposed to Al during development. Notwithstanding, Gonda and Lehotzky (1996) reported that the learning ability of the pups of rats given $9.8 \mathrm{mg} / \mathrm{kg} /$ day of $\mathrm{Al} \mathrm{lac-}$ tate on gestation Days 7-15 was impaired in a passive avoidance task, but no effect on the acquisition of a conditioned taste aversion was noted. In turn, Poulos and associates (Poulos et al., 1996) showed that oral $\mathrm{Al}$ administration to rats $(300 \mathrm{mg} / \mathrm{kg} /$ day $)$ during pregnancy and lactation produced delay in the development of the central nervous system of their pups. In the present study, Al exposure only tended to reduce the time spent in a rotarod, whereas concurrent exposure of maternal $\mathrm{Al}$ and restraint seemed to improve this performance. Although the passive avoidance conditioning test suggested an impaired retention in the mice in the group exposed to maternal $\mathrm{Al}$ plus restraint, an overall effect of $\mathrm{Al}$ and restraint was not found.

With regard to the developmental landmarks, incisor eruption, eye opening, and the sexual maturation of males and females were significantly delayed in the pups of dams concurrently exposed to Al plus restraint, in relation to those of the unrestrained control group. The 
number of days at incisor eruption was also significantly higher in the Al plus restraint group than in the group given $\mathrm{Al}$ only, whereas no significant differences between the group subjected to restraint only and the group exposed to Al plus restraint could be seen in the number of days at testes descent. In turn, Al exposure caused a significant increase in the number of days at pinna detachment independently of whether dams were restrained or unrestrained. Generally, $\mathrm{Al}$ treatment caused a significant reduction in body weight of both male and female pups. Moreover, on postnatal Day 21, pup body weight was significantly lower in the group whose mothers were concurrently exposed to $\mathrm{Al}$ and restraint than in the groups given $\mathrm{Al}$ or restraint only. In comparison with the groups subjected to restraint only or exposed to $\mathrm{Al}$ alone, combined exposure to $\mathrm{Al}$ and restraint induced a significant delay in the sexual maturation of females, a significant delay in incisor eruption, and a significant reduction in body weight (both sexes). Differences in body weight increased with age, which suggests long-lasting effects of the combined exposure to $\mathrm{Al}$ and restraint.

In our study, although differences were not statistically significant, a decrease in the indices of viability and lactation could be observed in the pups of the group concurrently exposed to $\mathrm{Al}$ plus restraint, in comparison with the remaining groups. Although no significant effects of maternal Al plus restraint on the behavior (open-field activity, motor resistance and coordination in a rotarod, and passive avoidance) of the offspring could be noted, a significant influence of maternal stress on $\mathrm{Al}$-induced developmental effects was found. This agrees with the results of a recent study, in which it was shown that maternal restraint could enhance the embryo/fetal toxicity of $\mathrm{Al}$ in mice (Colomina et al., 1998). These findings can be useful in elucidation of the role of maternal stress on the developmental and neurobehavioral effects induced by toxic elements that are widespread in our environment.

\section{REFERENCES}

Bernuzzi, V., Desor, D., \& LeHr, P. R. (1989a). Developmental alterations in offspring of female rats orally intoxicated by aluminum chloride or lactate during gestation. Teratology, 40, 21-27.

Bernuzzi, V., Desor, D., \& Lehr, P. R. (1989b). Effects of postnatal aluminum lactate exposure on neuromotor maturation in the rat. $\mathrm{Bul}$ letin of Environmental Contamination \& Toxicology, 42, 451-455.

BEYER, P. E., \& CHERNOFF, N. (1986). The induction of supernumerary ribs in rodents: Role of the maternal stress. Teratogenesis, Carcinogenesis \& Mutagenesis, 6, 419-429.

Chernoff, N., Miller, D. B., Rosen, M. R., \& Mattscheck, C. L. (1988). Developmental effects of maternal stress in the CD-1 mouse induced by restraint on single days during the period of major organogenesis. Toxicology, 51, 57-65.

Chernoff, N., Rogers, J., \& Kavlock, R. J. (1989). An overview of maternal toxicity and prenatal development: Considerations for developmental toxicity hazard assessments. Toxicology, 59, 111-125.

Cherroret, G., Bernuzzi, V., Desor, D., Hutin, M. F., Burnel, D., \& LEHR, P. R. (1992). Effects of postnatal aluminum exposure on choline acetyltransferase activity and learning abilities in the rat. Neurotoxicology \& Teratology, 14, 259-264.
Colomina, M. T., Albina, M. L., Domingo, J. L., \& Corbella, J. (1995). Effects of maternal stress on methylmercury-induced developmental toxicity in mice. Physiology \& Behavior, 58, 979-983.

Colomina, M. T., Albina, M. L., Domingo, J. L., \& Corbella, J. (1996). Influence of maternal restraint stress on arsenic-induced preand postnatal alterations in mice. Psychobiology, 24, 227-234.

Colomina, M. T., Albina, M. L., Domingo, J. L., \& Corbella, J. (1997). Influence of maternal stress on the effects of prenatal exposure to methylmercury and arsenic on postnatal development and behavior in mice: A preliminary evaluation. Physiology \& Behavior, 61, 455-459.

Colomina, M. T., Esparza, J. L., Corbella, J., \& Domingo, J. L. (1998). The effect of maternal restraint on developmental toxicity of aluminum in mice. Neurotoxicology \& Teratology, 20, 651-656.

Colomina, M. T., Sanchez, D. J., Albina, M. L., Domingo, J. L., \& Corbella, J. (1997). Effects of maternal stress on concurrent prenatal exposure to ethanol and methylmercury: II. Postnatal development and neurobehavior. Research Communications in Alcohol \& Substances of Abuse, 18, 57-70.

Domingo, J. L. (1995). Reproductive and developmental toxicity of aluminum: A review. Neurotoxicology \& Teratology, 17, 515-521.

Domingo, J. L. (1997). Development and aluminum experimental toxicity. In P. F. Zatta \& A. C. Alfrey (Eds.), Aluminum toxicity in infant's health (pp. 140-153). Singapore: World Scientific.

Domingo, J. L., Gomez, M., LlobeT, J. M., \& Corbella, J. (1991). Influence of some dietary constituents on aluminum absorption and retention in rats. Kidney International, 39, 598-601.

Domingo, J. L., Paternain, J. L., Llobet, J. M., \& Corbella, J. (1987a). The effects of aluminum ingestion on reproduction and postnatal survival in rats. Life Sciences, 41, 1127-1131.

Domingo, J. L., Paternain, J. L., Llobet, J. M., \& Corbella, J. (1987b). Effects of oral aluminum administration on perinatal and postnatal development in rats. Research Communications in Chemical Pathology \& Pharmacology, 57, 129-132.

Donald, J. M., Golub, M. S., Gershwin, M. E., \& KeEn, C. L. (1989). Neurobehavioral effects in offspring of mice given excess aluminum in diet during gestation and lactation. Neurotoxicology \& Teratology. 11, 341-351.

Ferm, V. H., \& Kilham, L. (1977). Synergistic teratogenic effects of arsenic and hyperthermia in hamsters. Environmental Research, 14, 483-486.

Golub, M. S., \& Domingo, J. L. (1996). What we know and what we need to know about developmental aluminum toxicity. Journal of Toxicology \& Environmental Health, 48, 585-597.

Golub, M. S., Donald, J. M., Gershwin, M. E., \& Keen, C. L. (1989). Effects of aluminum ingestion on spontaneous motor activity of mice. Neurotoxicology \& Teratology, 11, 231-235.

Golub, M. S., Gershwin, M. E., Donald, J. M., Negri, S., \& Keen, C. L. (1987). Maternal and developmental toxicity of chronic aluminum exposure in mice. Fundamental \& Applied Toxicology, 8, 346-357.

Golub, M. S., HAN, B., \& KeEN, C. L. (1996). Iron and manganese uptake by offspring of lactating mice fed a high aluminum diet. Toxicology, 109, 111-118.

Golub, M. S., Han, B., Keen, C. L., Gershwin, M. E., \& Tarara, R. P. (1995). Behavioral performance of Swiss Webster mice exposed to excess dietary aluminum during development or during development and as adults. Toxicology \& Applied Pharmacology, 133, 64-72.

Golub, M. S., Keen, C. L., \& Gershwin, M. E. (1992). Neurodevelopmental effects of aluminum in mice: Fostering studies. Neurotoxicology \& Teratology, 14, 177-182.

GONDA, Z., \& LEHOTZKY, K. (1996). Effect of prenatal aluminum lactate exposure on conditioned taste aversion and passive avoidance task in the rat. Journal of Applied Toxicology, 16, 529-532.

Gonda, Z., LEHOTZKy, K., \& MikLosI, A. (1996). Neurotoxicity induced by prenatal aluminum exposure in rats. Neurotoxicology, 17, 459-470.

Muller, G., Bernuzzi, V., Desor, D., Hutin, M. F., Burnel, D., \& 
LEHR, P. R. (1990). Developmental alterations in offspring of female rats orally intoxicated by aluminum lactate at different gestation periods. Teratology, 42, 253-261.

Muller, G., Hutin, M. F., Burnel, D., \& Lehr, P. R. (1992). Aluminum transfer through milk in female rats intoxicated by aluminum chloride. Biological Trace Element Research, 34, 79-87.

Murata, M., Takigawa, H. M., \& Sakamoto, H. (1993). Teratogenic effects of noise and cadmium in mice: Does noise have teratogenic potential? Journal of Toxicology \& Environmental Health, 39, 237-245.

Poulos, B. K., Perazzolo, M., Lee, V. M. Y., Rudelli, R., WisNIEWSKI, H. M., \& SOIFER, D. (1996). Oral aluminum administration during pregnancy and lactation produces gastric and renal lesions in rat mothers and delay in CNS development of their pups. Molecular \& Chemical Neuropathology, 29, 15-26.

RAsCo, J. F., \& HooD, R. D. (1994). Effects of maternal restraint stress and sodium arsenate in mice. Reproductive Toxicology, 8, 49-54.

Sanchez, D. J., Colomina, M. T., \& Domingo, J. L. (1998). Effects of vanadium on activity and learning in rats. Physiology \& Behavior, 63, 345-350.

SCIALli, A. R. (1988). Is stress a developmental toxin? Reproductive Toxicology 1, 163-171.
SUTER, K. E., \& SCHÖN, H. (1986). Testing strategies in behavioral teratology: I. Testing battery approach. Neurobehavioral Toxicology \& Teratology, 8, 561-566.

VoGEL, W. H. (1993). The effect of stress on toxicological investigations. Human \& Experimental Toxicology, 12, 265-271.

YOKEL, R. A. (1984). Toxicity of aluminum exposure during lactation to the maternal and suckling rabbit. Toxicology \& Applied Pharmacology, 75, 35-43.

YOKEL, R. A. (1985). Toxicity of gestational aluminum exposure to the maternal rabbit and offspring. Toxicology \& Applied Pharmacology, 79, 121-133.

YoKEL, R. A. (1987). Toxicity of aluminum exposure to the neonatal and immature rabbit. Fundamental \& Applied Toxicology, 9, 795-806.

YoKeL, R. A. (1989). Aluminum produces age related behavioral toxicity in the rabbit. Neurotoxicology \& Teratology, 11, 237-242.

Yokel, R. A., \& MCNamara, P. J. (1985). Aluminum bioavailability and disposition in adult and immature rabbits. Toxicology \& Applied Pharmacology, 77, 344-352.

(Manuscript received March 2, 1999; revision accepted for publication July 12, 1999.) 